\title{
PRODUÇÃO VEGETAL E A CONSTRUÇÃO DO CONHECIMENTO: UMA EXPERIÊNCIA EM ANÁLISE E TECNOLOGIA DE SEMENTES
}

\section{VEGETABLE PRODUCTION AND THE KNOWLEDGE CONSTRUCTION: AN EXPERIENCE ON SEED ANALYSIS AND TECHNOLOGY}

\author{
Marilis Dallarmi MIGUEL \\ Orientador: Professor Dr. Luiz DONI FILHO (Departamento de Fitotecnia e Fitossanitarismo - UFPR)
}

\begin{abstract}
RESUMO
O presente trabalho tem por objeto avaliar uma proposta pedagógica de ensino no Curso de Agronomia da UFPR. Neste intuito, pretende conscientizar os acadêmicos através de uma metodologia progressista sócio crítica, para atuarem como agentes de mudança social, conscientes da realidade histórica. A pesquisa trabalhou o cotidiano da disciplina de Análise e Tecnologia de Sementes. Criaramse estratégias de abordagem do respectivo conteúdo: promover o desenvolvimento de alunos no sentido lógico, crítico, criativo e cidadão em prol da construção do conhecimento. Privilegiou-se o trabalho coletivo e individual e um elenco de estratégias sob interação direta com o campo real de atuação profissional do Engenheiro Agrônomo. Utilizou-se para análise dos resultados o

alunos aliado a um instrumento de avaliação contendo 28 questões de múltipla escolha e 11 questões abertas. Buscou-se pesquisar como oportunizar a formação de um profissional reflexivo sobre sua ação, provocador lógico dos conhecimentos, com ações criativas em sua área, autônomo e emancipado. Nessa perspectiva, constatou-se ser posível transformar a formação do Engenheiro Agrônomo, desde que se tenha um planejamento pedagógico cuja intenção proponha um professor competente, que domine sua área do conhecimento, seja um pesquisador, um motivador no processo e que esteja aberto às discussões, domine a prática pedagógica e exercite no seu cotidiano o ser e estar de um professor engenheiro agrônomo e não o contrário.
\end{abstract} cumprimento das diferentes etapas vivenciadas pelos

\section{ABSTRACT}

The purpose of this work is to evaluate a teaching pedagogic proposal for the agronomic course of UFPR. Using a social critical progressist methodology, it is Intended to make the agronomic students aware of acting as social changing agents. conscious of their historic reality. It focuses on making the teaching methods feasible under the constructive optical. The research worked with the everyday of the discipline of seed technology and analysis, where it created strategies to broach the matter refered, to promote the development of students on a logic, creative, critical, citizen sense, on behalf of the construction of knowledge. It lavours the collective and individual work and a series of strategies under a direct interaction with the real performance of the agronomic engineering professional. To valuate the students, 28 multiple choice questions and 11 open questions were employed beyond those questions, they observed the accomplishment of the stages they came through. The main goal of this work was to stimulate the reflexive, conscious and ethnic formation. This procedure made possible to change the agronomic engineering formation. This pedagogics planning were requested, which should be made by a competent professor. This professor has to dominate this area of knowledge and to be a good researcher to promote the progress. He has to be open to discuss and dominate de pedagogic practices and exercise the acting as professor of agronomic engineering, not the contrary. 